\title{
Effect of Intercropping Patterns and Plant Distribution of Guar with Maize
}

\author{
Mahdy A.Y \\ Agron. Dept., Fac. Agric., El-Azhar Univ. Assiut, Egypt
}

\begin{abstract}
The present study was carried out at the Agriculture Experimental Farm of Al-Azhar University at Assiut Governorate, Egypt, during 2016 and 2017 seasons to study the effect of intercropping maize \{Zea mays, L. $\}$ cv. Threeway cross Nefertiti -3 , as the main crop with guar $\{$ Cyamposis tetragonoloba $\} \mathrm{cv}$. Local variety as secondary crop. The results could be summarized as follows: Pattern of $\left(\mathrm{P}_{1}\right)$ Sgnificantly increased plant height of maize as compared with pure stand and other intercropping patterns. The intercropping pattern of $\left(\mathrm{P}_{9}\right)$ maize produced the greatest values of 100grain weight (g), grains weight / plant (g) and grain yield (ardab /fad.). Significant increase in plant height and leaf area index of guar at all intercropping patterns were detected as compared with the pure stand, While, the number of leaves/plant were of guar decreased at all intercropping patterns as compared with pure stand. The pure stand of guar produced the maximum forage yield/fad. as compared with other intercropping patterns in both seasons. Meanwhile, growing guar under the intercropping pattern of $\left(\mathrm{P}_{2}\right)$ produced the highest values of forage yield/fad., as compared with the other intercropping patterns in both seasons. The protein ratio/plant and total ash/plant of grown guar under intercropping pattern of $\left(\mathrm{P}_{6}\right)$ produced the maximum as compared with all the other intercropping patterns in both seasons. The highest value of crude fibers for the guar was recorded $\left(\mathrm{P}_{4}\right)$ intercropping pattern. Intercropping pattern $\left(\mathrm{P}_{3}\right)$ was the best for land utilization from land equivalent ratio (LER) and relative crowding coefficient (RCC). Maize (dominant) and guar had the lowest values for aggressivity. All intercropping patterns of guar with maize achieved higher economic return than pure maize and the most profitable pattern was $\left(\mathrm{P}_{3}\right)$.
\end{abstract}

Key words: Maize, Guar, Intercropping Patterns and Plant Distribution.

\section{INTRODUCTION}

Maize is one of the most important cereal crops in the world agricultural economic either as food or as feed. In Egypt, maize is one of the most important cereal crops for human consumption and animal feeding. In addition, several industries are based on products and by - products of maize. Planted area of summer forage crops in Egypt is not sufficient for meat animal's requirements. Farmers used to defoliate maize plants as green fodder for cattle, which resulted in reducing maize yield. The need for an intensive cropping system, to raise the production per land unit is a great target. Intercropping is becoming one of the most popular phenomena among the small young farmers in Egypt. Reasons for this popularity results in more profit and resource maximization and efficient water and soil utilization. Among the many intercropping companions adopted, successfully, are those of sorghum and bean varieties. Because of the importance of legumes in human and animal nutrition, in summer, we have no land to grow any of these legumes. Hitherto, intercropping was the most suitable guide in guar cultivation with maize in summer season.. Akbar et al. (2012) mentioned that in conclusion, to get better yield of quality fodder (crude protein - crude fibers - total ash), forage maize should be intercropped with forage legumes, preferably cow pea, under the planting pattern of $30 \mathrm{~cm}$ spaced lines in alternate rows. El Aref et al. (2013) results indicated that the $\left(\mathrm{P}_{5}\right)$ system was the best for land utilization from land equivalent ratio (LER) and the most efficient intercropping system was obtained from relative crowding coefficient (RCC), although, it was more aggressive on maize. Mahdy and El-Said (2015) results of the economic return per fed. for intercropping forage crops with sesame revealed that all intercropping patterns under testing realized more net income and relative net income than the pure stands of forage crops or pure stand of sesame during the two experimental seasons, reaching their maximum with $\left(\mathrm{P}_{2}\right)$ cropping system in both seasons. Mahdy and El-Said (2017) results indicated that the the pure stands of the guar plants produced the maximum forage yield/fad as compared with the other intercropping patterns in both seasons. Meanwhile, growing guar under the intercropping pattern of $\left(\mathrm{P}_{9}\right)$ produced the highest values of forage yield/fad. as compared with the other intercropping patterns in both seasons. The protein ratio/plant grown soybean under intercropping pattern of $\left(\mathrm{P}_{11}\right)$, produced the maximum as compared with all other intercropping patterns. Meanwhile, growing soybean under the intercropping pattern of $\left(\mathrm{P}_{2}\right)$ produced the highest value of oil ratio of seeds/plant.Therefore, the main objective of this study was undertaken to examine the effect of intercropping patterns and plant distribution of guar with maize.

\section{MATERIALS AND METHODS}

The present study was carried out at the Experimental Farm of Al-Azhar University at 
Assiut Governorate, Egypt, during the summer of 2016 and 2017 seasons to study the effect of intercropping maize $\{$ Zea mays, L. $\}$ cv. Three waycross Nefertiti - 3, as the main crop with guar $\{/$ Cyamposis tetragonoloba $\} \mathrm{cv}$. Local variety as secondary crop on growth, yield and yield components, chemical analysis, competitive relationships and the economic return. The preceding crop was field bean $\{$ Vicia faba, (L.) $\}$ for all experiments in the two seasons.

A split -plot design, with three replications, was used.

(A) The main plots were devoted to the following intercropping patterns of guar with maize.

1-The first pattern $\left(\mathbf{S}_{\mathbf{1}}\right): 100 \%$ main crop $+100 \%$ secondary crop.

2- The second pattern $\left(\mathbf{S}_{\mathbf{2}}\right): 100 \%$ main crop +75 $\%$ secondary crop (by growing secondary crop on three maize ridges and leaving one maize ridge without intercropping).

3- The third pattern $\left(\mathbf{S}_{3}\right): 100 \%$ main crop $+50 \%$ secondary crop (by growing secondary crop on one maize ridge and leaving one maize ridge without intercropping).

(B) The sub - plots were assigned to three plant distribution of guar with maize as follows:-

1- First plant distribution $\left(\mathbf{T}_{1}\right)$ : Planting one plant / hill of guar $10 \mathrm{~cm}$ apart.

2- Second plant distribution $\left(\mathbf{T}_{2}\right)$ : Planting two plants / hill of guar $20 \mathrm{~cm}$ apart.

3- Third plant distribution $\left(\mathbf{T}_{3}\right)$ : Planting three plants / hill of guar $30 \mathrm{~cm}$ apart.

In all intercropping patterns and pure stand, maize (cv. Three way-cross Nefertiti - 3) was planted at $25 \mathrm{~cm}$ apart and growing one plant / hill on one side of the ridges, as well as guar pure stand (Local variety) which was planted at $10 \mathrm{~cm}$ apart and growing two plants / hill on two side of the ridges. Sub - plot area was $8.4 \mathrm{~m}^{2}(2.8 \mathrm{~m}$. width and $3 \mathrm{~m}$. length). The plot consisted of 4 ridges spaced
$70 \mathrm{~cm}$ apart of pure stands and intercropping patterns. The soil type was clay, with $\mathrm{P} \mathrm{H}$ value of 7.6 and $25 \%$ organic matter.

Maize and guar were seeded on May $14^{\text {th }}$ and $22^{\text {th }}$ in 2016 and 2017 seasons, respectively.

Calcium superphosphate $\left(15 \% \mathrm{P}_{2} \mathrm{O}_{5}\right)$ at a rate of 150 $\mathrm{kg} /$ fad. was applied during land preparation. Nitrogen, in the form of ammonium nitrate (33\% $\mathrm{N})$ at a rate of $120 \mathrm{~kg} \mathrm{~N} /$ fad., was added in two equal doses, before the first and the second irrigations. Other normal practices were adopted, as usually done as a recommended.

\section{Characters studied}

(1) Maize (main crop): At harvesting, the ears were harvested from the middle ridge of each plot in the two seasons and the following data were recorded:

A- Plant height in $(\mathrm{cm})$, was measured from soil surface to the top of the plant.

B - 100-grain weight (g).

C- Grains weight/plant (g).

D- Grain yield (Ardab/fad): Ardab = $140 \mathrm{~kg}$ (moisture 15.5\%).

(2) Guar (secondary crop):

A- Plant height in $\mathrm{cm}$, was measured from soil surface to the top of the plant.

B- Number of leaves/plant.

C- Leaf area index (LAI) as recorded for guar by disk method, which was recommended by Johanson (1967).

D- Forage yield (Ton/fad.) taking one cut after sixty days from sowing.

(3) Chemical analysis:

A- Determination of crude protein (C P): Total nitrogen content, in plant, was estimated by using microkjeldahl method, as described by A.O.A.C (1980) and percentage of protein was calculated by multiplying the nitrogen percentage by 6.25 .

Table 1: plant density for both components of different treatments.

\begin{tabular}{|c|c|c|c|c|c|c|}
\hline \multirow{2}{*}{ 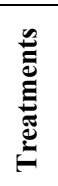 } & & & & \multicolumn{3}{|c|}{ Plant population density / fad. } \\
\hline & \multicolumn{3}{|c|}{ Intercropping patterns secondary crop } & Maize & Guar & Total \\
\hline $\mathrm{P}_{1}$ & \multirow{3}{*}{$\left(\mathrm{S}_{1}\right) \quad 100 \%$} & $\left(\mathrm{~T}_{1}\right)$ & One plant / hill of guar a $10 \mathrm{~cm}$ apart. & 22858 & 57142 & 80000 \\
\hline $\mathrm{P}_{2}$ & & $\left(\mathrm{~T}_{2}\right)$ & Two plants / hill of guar $20 \mathrm{~cm}$ apart. & 22858 & 57142 & 80000 \\
\hline $\mathrm{P}_{3}$ & & $\left(T_{3}\right)$ & Three plants / hill of guar $30 \mathrm{~cm}$ apart. & 22858 & 57142 & 80000 \\
\hline $\mathrm{P}_{4}$ & \multirow{3}{*}{$\left(S_{2}\right) 75 \%$} & $\left(\mathrm{~T}_{1}\right)$ & One plant / hill of guar $10 \mathrm{~cm}$ apart. & 22858 & 42857 & 65715 \\
\hline $\mathrm{P}_{5}$ & & $\left(\mathrm{~T}_{2}\right)$ & Two plants / hill of guar $20 \mathrm{~cm}$ apart. & 22858 & 42857 & 65715 \\
\hline $\mathrm{P}_{6}$ & & $\left(\mathrm{~T}_{3}\right)$ & Three plants / hill of guar $30 \mathrm{~cm}$ apart. & 22858 & 42857 & 65715 \\
\hline $\mathrm{P}_{7}$ & \multirow{3}{*}{$\left(\mathrm{S}_{3}\right) 50 \%$} & $\left(\mathrm{~T}_{1}\right)$ & One plant / hill of guar $10 \mathrm{~cm}$ apart. & 22858 & 28571 & 51429 \\
\hline $\mathrm{P}_{8}$ & & $\left(T_{2}\right)$ & Two plants / hill of guar $20 \mathrm{~cm}$ apart. & 22858 & 28571 & 51429 \\
\hline $\mathrm{P}_{9}$ & & $\left(\mathrm{~T}_{3}\right)$ & Three plants / hill of guar $30 \mathrm{~cm}$ apart. & 22858 & 28571 & 51429 \\
\hline$P_{10}$ & & & Solid maize & 22858 & - & 22858 \\
\hline $\mathrm{P}_{11}$ & & & Solid guar & - & 114285 & 114285 \\
\hline
\end{tabular}


B- Determination of total ash content (TAC): The total ash content was determined by heating the samples $(0.5-2.0 \mathrm{~g})$ in an about 600 $+10{ }^{0} \mathrm{C}$ for $3 \mathrm{hr}$ until they were completely ashes A.O.A.C (1975).

C- Determination of crude fibers (C F): The crude fibers content was determined according to the official method A.O.A.C (1975).

4- Competitive relationships and yield advantages of intercropping:

A- Land equivalent ratio (LER) was estimated according to Willey (1979).

B- Relative crowding coefficient (RCC) was calculated as described by Hall (1974).

C- Aggressively (A) was determined according to Mc-Gilchrist (1965).

5 - The Economic return:

Net income, in Egyptian pounds/fad., for pure stands of maize and guar as well as intercropping patterns guar with maize, was estimated. Price of the yield and the cost of agricultural practices were considered, according to the Ministry of Agriculture, Agricultural Research Center, Central Admen of Agric. in 2016 and 2017.

6 - Statistical analysis:

The data were statistically analyzed according to procedures outlined by Steel and Torrie (1980). Least significant difference (L.S.D.), at $5 \%$ level of probability, was used to compare among treatment means.

\section{RESULTS AND DISCUSSION}

1. The effect of intercropping on maize crop: The effect of applied intercropping patterns on yield and yield components of maize, as combined with guar during 2016 and 2017 seasons, is presented in Table 2.

Maize, grown under the intercropping pattern of $\left(\mathrm{P}_{1}\right)$ resulted in the tallest plant as compared to the pure stand or the other intercropping patterns, during the two experimental seasons. On the other hand, the shortest maize plants were produced from planting the pure stand, during the two seasons.

Results in Table 2 show that the intercropping pattern of $\left(\mathrm{P}_{9}\right)$ which contained the plant population density of maize, 22858 plants/fad. combined with 28571 plants/fad. of guar, produced the highest values of 100-grain weight $(\mathrm{g})$, grain weight / plant (g) and grain yield (ardab /fad.) as compared to the intercropping patterns during 2016 and 2017 seasons. The competition between maize and guar was high because of close distances between guar. As the number of increased guar sides, the competition was not too much to reduce 100-grain weight $(\mathrm{g})$, grains weight / plant $(\mathrm{g})$ and grain yield ( $\operatorname{ardab} / \mathrm{fad}$.) of maize.

The pure stand of maize had the highest 100grain weight $(\mathrm{g})$, grains weight / plant $(\mathrm{g})$ and grain yield (ardab /fad.) of maize in both seasons.

Generally, the results in Table 2 clarify that the maize planting under the intercropping pattern $\left(\mathrm{P}_{1}\right)$ which contained the plant population density of maize, 22858 plants/fad. combined with 57142 plants/fad. of guar, led to decrease the values of No. of branchs/plant, 100-grain weight (g), grain weight / plant (g) and grain yield (ardab /fad.) as compared with the pure stand or all the other intercropping patterns during in both seasons. These results are in agreement with Kamal - Eldin (2010), Haruna et al. (2013), Abdel - Galil and Abdel - Chany (2014), Puste et al. (2014) and Oyeogbe et al. (2015).

\section{2- Effect of intercropping on guar:}

A- Growth characters and forage yield (ton/fad.):

Results in Table 3 showed the effect of intercropping patterns on average plant height, number of leaves/plant and leaf area index of guar during 2016 and 2017 seasons.

Table 2: Effect of intercropping on yield and some agricultural characters of maize.

\begin{tabular}{|c|c|c|c|c|c|c|c|c|c|c|}
\hline \multicolumn{3}{|c|}{ Treatments } & \multicolumn{2}{|c|}{$\begin{array}{l}\text { Plant height } \\
\text { (cm.) }\end{array}$} & \multicolumn{2}{|c|}{$\begin{array}{l}\text { 100-grain weight } \\
\text { (g) }\end{array}$} & \multicolumn{2}{|c|}{$\begin{array}{c}\text { Grains weight / plant } \\
\text { (g) }\end{array}$} & \multicolumn{2}{|c|}{$\begin{array}{l}\text { Grain yield } \\
\text { (ardab/fad.) }\end{array}$} \\
\hline & & & 2016 & 2017 & 2016 & 2017 & 2016 & 2017 & 2016 & 2017 \\
\hline $\mathrm{P}_{1}$ & \multirow{3}{*}{$\mathrm{S}_{1}$} & $\mathrm{~T}_{1}$ & 277.21 & 280.56 & 35.07 & 34.11 & 175.24 & 175.94 & 20.21 & 19.85 \\
\hline $\mathrm{P}_{2}$ & & $\mathrm{~T}_{2}$ & 268.47 & 269.94 & 40.92 & 41.33 & 185.14 & 186.55 & 22.00 & 22.33 \\
\hline $\mathrm{P}_{3}$ & & $\mathrm{~T}_{3}$ & 256.00 & 257.90 & 45.27 & 44.00 & 195.23 & 194.83 & 23.70 & 23.91 \\
\hline $\mathrm{P}_{4}$ & \multirow{3}{*}{$\mathrm{S}_{2}$} & $\mathrm{~T}_{1}$ & 271.54 & 273.88 & 37.55 & 36.15 & 178.56 & 177.16 & 21.34 & 21.67 \\
\hline $\mathrm{P}_{5}$ & & $\mathrm{~T}_{2}$ & 264.35 & 267.00 & 41.66 & 42.00 & 189.66 & 190.18 & 22.46 & 22.20 \\
\hline $\mathrm{P}_{6}$ & & $\mathrm{~T}_{3}$ & 252.77 & 250.98 & 46.94 & 47.42 & 197.70 & 196.00 & 23.97 & 23.50 \\
\hline $\mathrm{P}_{7}$ & \multirow{3}{*}{$\mathrm{S}_{3}$} & $\mathrm{~T}_{1}$ & 268.44 & 270.00 & 38.39 & 39.28 & 180.57 & 182.27 & 21.90 & 21.34 \\
\hline $\mathrm{P}_{8}$ & & $\mathrm{~T}_{2}$ & 260.91 & 261.11 & 43.55 & 42.74 & 192.00 & 193.99 & 23.12 & 23.00 \\
\hline $\mathrm{P}_{9}$ & & $\mathrm{~T}_{3}$ & 250.24 & 253.61 & 48.38 & 48.98 & 203.11 & 201.87 & 24.39 & 24.10 \\
\hline $\mathrm{P}_{10}$ & \multicolumn{2}{|c|}{ Soled maize } & 244.69 & 248.26 & 51.17 & 54.69 & 207.82 & 209.45 & 24.81 & 25.28 \\
\hline \multicolumn{3}{|c|}{ L.S.D. 5\% } & 2.11 & 1.97 & 2.43 & 2.88 & 3.29 & 4.13 & 2.19 & 2.54 \\
\hline
\end{tabular}


Table 3: Effect of maize- guar intercropping patterns on growth character of guar during 2016 and 2017 seasons.

\begin{tabular}{|c|c|c|c|c|c|c|c|c|c|c|}
\hline \multicolumn{3}{|c|}{ Treatments } & \multicolumn{2}{|c|}{ Plant height (cm) } & \multicolumn{2}{|c|}{$\begin{array}{c}\text { Number of leaves } \\
\text { / plant }\end{array}$} & \multicolumn{2}{|c|}{$\begin{array}{c}\text { Leaf area index } \\
\text { (LAI) }\end{array}$} & \multicolumn{2}{|c|}{$\begin{array}{c}\text { Forage yield } \\
\text { (ton/fad.) }\end{array}$} \\
\hline & & & 2016 & 2017 & 2017 & 2017 & 2017 & 2017 & 2016 & 2017 \\
\hline $\mathrm{P}_{1}$ & \multirow{3}{*}{$\mathrm{S}_{1}$} & $\mathrm{~T}_{1}$ & 88.75 & 89.56 & 30.55 & 31.91 & 2.25 & 2.37 & 14.197 & 14.065 \\
\hline $\mathrm{P}_{2}$ & & $\mathrm{~T}_{2}$ & 80.94 & 82.19 & 38.66 & 38.00 & 2.77 & 2.59 & 14.930 & 14.746 \\
\hline $\mathrm{P}_{3}$ & & $\mathrm{~T}_{3}$ & 72.25 & 73.66 & 44.15 & 43.84 & 3.11 & 3.00 & 14.541 & 14.370 \\
\hline $\mathrm{P}_{4}$ & \multirow{3}{*}{$\mathrm{S}_{2}$} & $\mathrm{~T}_{1}$ & 85.66 & 87.28 & 33.94 & 34.11 & 2.29 & 2.50 & 12.377 & 12.109 \\
\hline $\mathrm{P}_{5}$ & & $\mathrm{~T}_{2}$ & 78.42 & 78.84 & 40.00 & 41.55 & 2.85 & 2.91 & 12.711 & 12.900 \\
\hline $\mathrm{P}_{6}$ & & $\mathrm{~T}_{3}$ & 69.11 & 71.47 & 46.33 & 45.70 & 3.33 & 3.20 & 12.406 & 12.611 \\
\hline $\mathrm{P}_{7}$ & \multirow{3}{*}{$\mathrm{S}_{3}$} & $\mathrm{~T}_{1}$ & 84.22 & 86.35 & 35.24 & 36.67 & 2.38 & 2.47 & 8.924 & 9.224 \\
\hline $\mathrm{P}_{8}$ & & $\mathrm{~T}_{2}$ & 75.33 & 76.94 & 41.85 & 43.00 & 2.90 & 2.99 & 9.842 & 10.017 \\
\hline $\mathrm{P}_{9}$ & & $\mathrm{~T}_{3}$ & 67.80 & 68.00 & 48.74 & 47.94 & 3.69 & 3.64 & 9.333 & 9.780 \\
\hline$P_{10}$ & \multicolumn{2}{|c|}{ Soled guar } & 65.17 & 64.34 & 52.86 & 54.18 & 1.88 & 1.90 & 16.517 & 17.000 \\
\hline \multicolumn{3}{|c|}{ L.S.D. $5 \%$} & 2.33 & 2.71 & 1.88 & 1.64 & 0.18 & 0.25 & 2.75 & 2.44 \\
\hline
\end{tabular}

Results, in Table 3 showed that the intercropping patterns had a significant effect on guar plant height during 2016 and 2017 seasons. The guar grown under intercropping pattern of $\left(\mathrm{P}_{1}\right)$ which contains the population density of maize, 22858 plants/fad. combined with 57142 plants/fad. of guar, gave the tallest plants as compared with the pure stand and all the other intercropping patterns in both seasons.

Results in Table 3 showed that intercropping patterns had significant effect on number of leaves per plant of guar in both seasons. Generally, it is clear that number of leaves/plant of guar tended to decrease when grown under the different intercropping patterns as compared with the pure stand. The guar crop sown under the intercropping pattern $\left(\mathrm{P}_{9}\right)$ which contains the population density of maize 22858 plants/fad., combined with 28571 plants/fad. of guar showed a highest number of leaves/plant as compared with the other intercropping patterns in 2016 and 2017 seasons. While, the intercropping pattern of $\left(\mathrm{P}_{1}\right)$ was the lowest number of leaves/plant as compared with the other intercropping patterns.

Concerning the effect of the applied intercropping patterns on LAI, results recorded in Table 3 showed a significant effect on the leaf area index (LAI) for guar plants during 2016 and 2017 seasons.

The intercropping pattern $\left(\mathrm{P}_{9}\right)$ of guar produced the highest values of LAI as compared with the pure stand or the other intercropping patterns in both seasons, While, the intercropping pattern of $\left(\mathrm{P}_{1}\right)$ of guar led to reduction in the LAI of guar as compared with other intercropping patterns during 2016 and 2017 seasons. The lowest values of LAI were recorded for pure stand of guar, as compared with all the other intercropping patterns in both seasons. These results are in agreement with those obtained by Adeniyan et al. (2011) and Akbar et al. (2012).
The effect of applied intercropping patterns on forage yield (ton/fad.) of guar as grown with maize in 2016 and 2017 seasons is presented in Table 3.

The pure stand, of the guar plants, produced the maximum forage yield (ton/fad.) as compared with the other intercropping patterns in both seasons. Meanwhile, the guar, grown under the intercropping pattern of $\left(\mathrm{P}_{2}\right)$ when plant population density of maize, 22858 plants/fad., combined with 57142 plants/fad. of guar, produced the highest values of forage yield (ton/fad.) as compared with the other intercropping patterns in both seasons. On the other hand, the guar plants grown under the intercropping pattern of $\left(\mathrm{P}_{7}\right)$ which had the plant population density of maize, 22858 plants/fad. combined with 28571 plants/fad. of guar, produced the lowest forage yield (ton/fad.) as compared with the pure stand and the other intercropping patterns in both seasons. Similar results were obtained by Dahmardeh et al. (2010), Adeniyan et al. (2011), Akbar et al. (2012), Mahdy and El-Said (2015) and Mahdy and El-Said (2017).

\section{3- Chemical analysis:}

Concerning the protein ratio/plant and total ash /plant of guar, results in Table 4 revealed that the above mentioned characters were decreased significantly by intercropping as compared with the pure stand during the two seasons. Guar crop, grown under intercropping pattern $\left(\mathrm{P}_{6}\right)$ which contains the population density of maize, 22858 plants/fad. combined with 42857 plants/fad. of guar, had the highest value of protein content/plant and total ash/plant as compared with all the other intercropping patterns during both seasons. while, the intercropping pattern of $\left(\mathrm{P}_{1}\right)$ which contain the population density of maize, 22858 plants/fad. combined with 57142 plants/fad. of guar, was the lowest values for these traits as than with the other intercropping patterns in both seasons. 
Table 4: Effect of intercropping on protein ratio / plant, total ash ratio / plant and crude fibers ratio / plant of guar during 2016 and 2017 seasons.

\begin{tabular}{|c|c|c|c|c|c|c|c|c|}
\hline \multicolumn{3}{|c|}{ Treatments } & \multicolumn{2}{|c|}{$\begin{array}{c}\text { Protein ratio / } \\
\text { plant }\end{array}$} & \multicolumn{2}{|c|}{$\begin{array}{c}\text { Total ash ratio / } \\
\text { plant }\end{array}$} & \multicolumn{2}{|c|}{$\begin{array}{c}\text { Crude fibers ratio / } \\
\text { plant }\end{array}$} \\
\hline & & & 2017 & 2017 & 2017 & 2017 & 2016 & 2017 \\
\hline $\mathrm{P}_{1}$ & \multirow{3}{*}{$\mathrm{S}_{1}$} & $\mathrm{~T}_{1}$ & 26.96 & 26.34 & 19.60 & 19.85 & 12.46 & 12.27 \\
\hline $\mathrm{P}_{2}$ & & $\mathrm{~T}_{2}$ & 28.81 & 28.54 & 22.12 & 22.29 & 11.85 & 11.55 \\
\hline $\mathrm{P}_{3}$ & & $\mathrm{~T}_{3}$ & 29.91 & 29.72 & 23.30 & 23.11 & 9.51 & 9.94 \\
\hline $\mathrm{P}_{4}$ & \multirow{3}{*}{$\mathrm{S}_{2}$} & $\mathrm{~T}_{1}$ & 27.39 & 27.83 & 21.64 & 21.93 & 12.72 & 12.87 \\
\hline $\mathrm{P}_{5}$ & & $\mathrm{~T}_{2}$ & 29.62 & 29.40 & 22.77 & 22.40 & 10.90 & 10.49 \\
\hline $\mathrm{P}_{6}$ & & $\mathrm{~T}_{3}$ & 30.75 & 30.59 & 24.53 & 24.79 & 9.66 & 9.42 \\
\hline $\mathrm{P}_{7}$ & \multirow{3}{*}{$\mathrm{S}_{3}$} & $\mathrm{~T}_{1}$ & 27.00 & 27.15 & 20.35 & 20.58 & 12.11 & 12.00 \\
\hline $\mathrm{P}_{8}$ & & $\mathrm{~T}_{2}$ & 29.17 & 29.28 & 22.41 & 22.00 & 10.25 & 10.62 \\
\hline $\mathrm{P}_{9}$ & & $\mathrm{~T}_{3}$ & 30.24 & 30.11 & 23.85 & 23.61 & 9.15 & 9.33 \\
\hline$P_{10}$ & \multicolumn{2}{|c|}{ Soled guar } & 31.17 & 31.99 & 25.57 & 26.33 & 8.70 & 8.20 \\
\hline \multicolumn{3}{|c|}{ L.S.D. 5\% } & 0.41 & 0.35 & 0.54 & 0.75 & 0.19 & 0.28 \\
\hline
\end{tabular}

The highest value of crude fibers for the guar, was obtained at $\left(\mathrm{P}_{3}\right)$ intercropping patterns at maize, population density of 22858 plants/fad. combined with 57142 plants/fad. of guar, while the lowest values of crude fibers from planting guar at the intercropping pattern of $\left(\mathrm{P}_{7}\right)$ in both seasons. Similar results were obtained by Elena and Roman (2010), Dahmardeh et al. (2010), Akbar et al. (2012) and Mahdy and El-Said (2017).

4- Competitive relationships of intercropping guar with maize:

\section{A. Land Equivalent Ratio (LER):}

Results in Table 5 show that there was a considerable yield advantage as results of intercropping guar with maize during 2016 and 2017 seasons. Results in Table 5 show that land equivalent ratio (LER) was increased over one by intercropping guar with maize in different patterns during 2016 and 2017 seasons. The highest LER values were obtained by intercropping pattern of $\left(\mathrm{P}_{3}\right)$ at which maize population density of 22858 plants/fad. combined with 57142 plants/fad. of guar in both seasons. These results are in agreement with those obtained by Ahmad et al (2010), Dahmardeh et al. (2010), Chivas et al. (2011), Addo - Quaye et al. (2011) and Quainoo1 et al. (2012), El - Aref et al. (2013) and Mahdy and El-Said (2017).

B. Relative crowding coefficient (RCC):

Results in Table 6 showed that the relative crowding coefficient (RCC) was also influenced by different intercropping patterns this measurement took treatments imposed in a similar trend as land equivalent ratio (LER) behavior during 2016 and 2017 seasons. The RCC values exceeded the unity indicating that net grain in yield was more than accepted from both components. The results, also, evidenced that increasing the plant density of maize and guar led to increase the total (RCC); i. e. , the highest total (RCC) resulted from growing 22858 plants/fad. of maize, combined with 57142 plants/fad. of guar, at $\left(\mathrm{P}_{3}\right)$ intercropping pattern. The same trend was reported by Chivas et al. (2011), Quainool et al. (2012), El - Aref et al. (2013) and Mahdy and El-Said (2017).

Table 5: Land equivalent ratio (LER) of maize and guar crop during 2016 and 2017 seasons.

\begin{tabular}{|c|c|c|c|c|c|c|c|c|}
\hline \multirow{3}{*}{ 递 } & \multirow{3}{*}{\multicolumn{2}{|c|}{$\begin{array}{c}\text { Intercropping } \\
\text { patterns with } \\
\text { Secondary crop }\end{array}$}} & \multicolumn{6}{|c|}{ Land equivalent ratio (LER) } \\
\hline & & & \multicolumn{3}{|c|}{2016} & \multicolumn{3}{|c|}{2017} \\
\hline & & & $\begin{array}{c}\text { Main } \\
\text { crop }\end{array}$ & $\begin{array}{c}\text { Secondary } \\
\text { crop }\end{array}$ & L.E.R. & $\begin{array}{c}\text { Main } \\
\text { crop }\end{array}$ & $\begin{array}{c}\text { Secondary } \\
\text { crop }\end{array}$ & L.E.R. \\
\hline $\mathrm{P}_{1}$ & \multirow{3}{*}{$\left(\mathrm{S}_{1}\right) \quad 100 \%$} & $\mathrm{~T}_{1}$ & 0.81 & 0.85 & 1.66 & 0.78 & 0.82 & 1.60 \\
\hline $\mathrm{P}_{2}$ & & $\mathrm{~T}_{2}$ & 0.88 & 0.90 & 1.78 & 0.88 & 0.86 & 1.74 \\
\hline $\mathrm{P}_{3}$ & & $\mathrm{~T}_{3}$ & 0.95 & 0.88 & 1.83 & 0.94 & 0.84 & 1.78 \\
\hline $\mathrm{P}_{4}$ & \multirow{3}{*}{$\left(S_{2}\right) 75 \%$} & $\mathrm{~T}_{1}$ & 0.86 & 0.74 & 1.60 & 0.85 & 0.71 & 1.56 \\
\hline $\mathrm{P}_{5}$ & & $\mathrm{~T}_{2}$ & 0.90 & 0.76 & 1.66 & 0.87 & 0.75 & 1.62 \\
\hline $\mathrm{P}_{6}$ & & $\mathrm{~T}_{3}$ & 0.96 & 0.75 & 1.71 & 0.92 & 0.74 & 1.66 \\
\hline $\mathrm{P}_{7}$ & \multirow{3}{*}{$\left(\mathrm{S}_{3}\right) 50 \%$} & $\mathrm{~T}_{1}$ & 0.88 & 0.54 & 1.42 & 0.84 & 0.54 & 1.38 \\
\hline $\mathrm{P}_{8}$ & & $\mathrm{~T}_{2}$ & 0.93 & 0.59 & 1.52 & 0.90 & 0.58 & 1.48 \\
\hline $\mathrm{P}_{9}$ & & $\mathrm{~T}_{3}$ & 0.98 & 0.56 & 1.54 & 0.95 & 0.57 & 1.52 \\
\hline
\end{tabular}


Table 6: Relative crowding coefficient (RCC) and Aggressivity (A) of maize and guar crop during 2016 and 2017 seasons.

\begin{tabular}{|c|c|c|c|c|c|c|c|c|c|c|c|c|}
\hline \multirow{3}{*}{ 莺 } & \multirow{3}{*}{\multicolumn{2}{|c|}{$\begin{array}{l}\text { Intercropping } \\
\text { patterns } \\
\text { secondary } \\
\text { crop }\end{array}$}} & \multicolumn{6}{|c|}{ Relative crowding coefficient (RCC) } & \multicolumn{4}{|c|}{ Aggressivity (A) } \\
\hline & & & \multicolumn{3}{|c|}{2016} & \multicolumn{3}{|c|}{2017} & \multicolumn{2}{|c|}{2016} & \multicolumn{2}{|c|}{2017} \\
\hline & & & 章 & 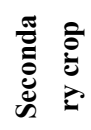 & $\begin{array}{l}\text { نِ } \\
\text { بِ }\end{array}$ & 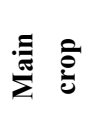 & 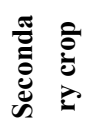 & 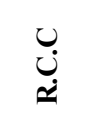 & 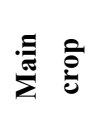 & 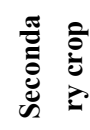 & 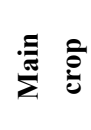 & 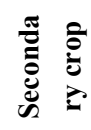 \\
\hline $\mathrm{P}_{1}$ & \multirow{3}{*}{$\begin{array}{l}\left(S_{1}\right) \\
100 \%\end{array}$} & $\mathrm{~T}_{1}$ & 1.75 & 15.30 & 26.77 & 1.46 & 12.05 & 17.59 & 15.25 & 15.25 & 14.66 & 14.66 \\
\hline $\mathrm{P}_{2}$ & & $\mathrm{~T}_{2}$ & 3.20 & 23.63 & 75.61 & 3.12 & 15.54 & 48.48 & 15.69 & 15.69 & 18.12 & 18.12 \\
\hline $\mathrm{P}_{3}$ & & $\mathrm{~T}_{3}$ & 8.45 & 18.40 & 155.4 & 6.97 & 13.58 & 94.65 & 14.24 & 14.24 & 13.35 & 13.35 \\
\hline $\mathrm{P}_{4}$ & \multirow{3}{*}{$\begin{array}{l}\left(S_{2}\right) \\
75 \%\end{array}$} & $\mathrm{~T}_{1}$ & 2.46 & 7.51 & 18.47 & 2.41 & 6.14 & 14.79 & 11.57 & 11.57 & 10.56 & 10.56 \\
\hline $\mathrm{P}_{5}$ & & $\mathrm{~T}_{2}$ & 3.90 & 8.34 & 32.52 & 3.08 & 7.89 & 24.30 & 11.64 & 11.64 & 11.64 & 11.64 \\
\hline $\mathrm{P}_{6}$ & & $\mathrm{~T}_{3}$ & 11.36 & 7.58 & 86.10 & 5.30 & 7.20 & 38.16 & 10.41 & 10.41 & 10.57 & 10.57 \\
\hline $\mathrm{P}_{7}$ & \multirow{3}{*}{$\begin{array}{c}\left(\mathrm{S}_{3}\right) \\
50 \%\end{array}$} & $\mathrm{~T}_{1}$ & 3.04 & 2.94 & 8.93 & 2.17 & 2.96 & 6.42 & 5.35 & 5.35 & 5.86 & 5.86 \\
\hline $\mathrm{P}_{8}$ & & $\mathrm{~T}_{2}$ & 5.71 & 3.69 & 21.06 & 4.21 & 3.62 & 15.24 & 6.37 & 6.37 & 6.44 & 6.44 \\
\hline $\mathrm{P}_{9}$ & & $\mathrm{~T}_{3}$ & 23.71 & 3.25 & 77.06 & 8.15 & 3.37 & 27.49 & 4.87 & 4.87 & 5.54 & 5.54 \\
\hline
\end{tabular}

\section{Aggressivity (A):}

Results in Table 6 showed that in both growing seasons of this study, maize was dominant at all intercropping patterns. Aggressivity values were the highest when guar was intercropped with maize at $\left(\mathrm{P}_{1}\right)$ intercropping pattern. It is also indicated that both maize and guar dominated. However, it could be concluded that the interspecific competition between maize and guar was pronounced in all intercropping patterns because of the differences in morphology of both crops. These results were also supported by Chivas et al. (2011), Quainool et al. (2012), El -Aref et al. (2013) and Mahdy and ElSaid (2017).

5- Economic return per L.E.

The economic return evaluation for either intercropping maize + guar at different intercropping patterns, compared with pure stand of maize were recorded in Table 7 during 2016 and
2017 seasons. It is clearly that all intercropping patterns for guar, as a companion crop with maize, although they were expensive, but they achieved a higher relative net profit than the pure stand of maize during the experimental seasons.

Results of the economic return per fad., for intercropping guar with maize revealed that all intercropping patterns under testing realized more net income and relative net income than the pure stand of maize or pure stand of guar during the two experimental seasons. In general, the comparison between, the intercropping pattern, which realized the highest grain yield of maize under intercropping guar with maize $\left(\mathrm{P}_{3}\right)$, also, realized the highest net income per fad. during the two experimental seasons. The results are in agreement with those obtained by Egbe and Idoko (2012), Mahdy and ElSaid (2015) and Mahdy and El-Said (2017).

Table 7: Effect of intercropping patterns of guar with maize on the economic return/fed. Egyptian pounds during 2016 and 2017 seasons.

\begin{tabular}{|c|c|c|c|c|c|c|c|c|c|c|}
\hline \multirow{2}{*}{\multicolumn{3}{|c|}{ Treatments }} & \multicolumn{3}{|c|}{2016} & \multicolumn{3}{|c|}{2017} & \multicolumn{2}{|c|}{ Relative net income } \\
\hline & & & \multirow{2}{*}{$\begin{array}{c}\begin{array}{c}\text { Price of } \\
\text { the yield }\end{array} \\
16795 \\
\end{array}$} & \multirow{2}{*}{$\begin{array}{c}\text { Cost } \\
9740 \\
\end{array}$} & \multirow{2}{*}{$\begin{array}{c}\begin{array}{c}\text { Net } \\
\text { income }\end{array} \\
7055 \\
\end{array}$} & \multirow{2}{*}{$\begin{array}{c}\begin{array}{c}\text { Price of } \\
\text { the yield }\end{array} \\
18.240 \\
\end{array}$} & \multirow{2}{*}{$\begin{array}{c}\text { Cost } \\
10950 \\
\end{array}$} & \multirow{2}{*}{$\begin{array}{c}\begin{array}{c}\text { Net } \\
\text { income }\end{array} \\
7290 \\
\end{array}$} & \multirow{2}{*}{$\begin{array}{l}2016 \\
136.0 \\
\end{array}$} & \multirow{2}{*}{$\begin{array}{r}\mathbf{2 0 1 7} \\
132.3 \\
\end{array}$} \\
\hline $\mathrm{P}_{1}$ & & $\mathrm{~T}_{1}$ & & & & & & & & \\
\hline $\mathrm{P}_{2}$ & $\mathrm{~S}_{1}$ & $\mathrm{~T}_{2}$ & 18072 & 9740 & 8332 & 19.974 & 10950 & 9024 & 160.6 & 163.8 \\
\hline $\mathrm{P}_{3}$ & & $\mathrm{~T}_{3}$ & 18851 & 9740 & 9111 & 20813 & 10950 & 9863 & 175.6 & 179.0 \\
\hline $\mathrm{P}_{4}$ & \multirow{3}{*}{$\mathrm{S}_{2}$} & $\mathrm{~T}_{4}$ & 16688 & 9740 & 6948 & 18449 & 10950 & 7499 & 133.9 & 136.1 \\
\hline $\mathrm{P}_{5}$ & & $\mathrm{~T}_{5}$ & 17603 & 9740 & 7863 & 19125 & 10950 & 8175 & 151.6 & 148.4 \\
\hline $\mathrm{P}_{6}$ & & $\mathrm{~T}_{6}$ & 18146 & 9740 & 8406 & 19775 & 10950 & 8825 & 162.0 & 160.2 \\
\hline $\mathrm{P}_{7}$ & \multirow{3}{*}{$\mathrm{S}_{3}$} & $\mathrm{~T}_{7}$ & 15615 & 9740 & 5875 & 16955 & 10950 & 6005 & 113.2 & 109.0 \\
\hline $\mathrm{P}_{8}$ & & $\mathrm{~T}_{8}$ & 16653 & 9740 & 6913 & 18308 & 10950 & 7385 & 133.3 & 134.0 \\
\hline $\mathrm{P}_{9}$ & & $\mathrm{~T}_{9}$ & 17.148 & 9740 & 7408 & 18861 & 10950 & 7911 & 142.8 & 143.6 \\
\hline \multicolumn{3}{|c|}{ Soled maize } & 13.646 & 8460 & 5186 & 15168 & 9660 & 5508 & 100.00 & 100.00 \\
\hline
\end{tabular}




\section{CONCLUSION AND RECOMMENDATION}

The application of intercropping patterns and plant distribution improved yield and yield components of maize and guar. Therefore, the study recommends treatment $\left(\mathrm{P}_{9}\right)$ of maize and treatment $\left(\mathrm{P}_{2}\right)$ of guar in order to improve the production under the conditions of Assiut Governorate, Egypt.

\section{REFERENCES}

Abdel - Galil, A. M. and R. E. Abdel - Chany (2014). Effect of groundnut - sesame intercropping and nitrogen fertilizer on yield, yield components and infection of root rot and wilt diseases. Inter. J. of Plant and Soil Sci. 3 (6): $623-643$.

Addo - Quaye, A. A.; A. A. Darkwa and G. K. Ocloo (2011). Yield and productivity of component crops in maize - soybean intercropping system as affected by time of planting and spatial arrangement. J. of Agric. and Biological Science 6 (9): 21-33.

Adeniyan O. N.; A. O. T.yoola and D. O. Ogunleti (2011). Evaluation of cow pea cultivars under maize and cassava based intercropping systems. Institute of Agricultural Research and Training, P. M. B. 5029. Ibadan, Nigeria.

Ahmad, A.; A. Riaz ; M. Naeem and A. Tanveer (2007). Performance of forage sorghum intercropped with forage legumes under different planting patterns. Pakistan J. of Botany 39 (2): 431 - 439.

Ahmad. G.; M. Dahmardeh; B. A. Siahsar and M. Ramroudi (2010). Effect of maize (Zea mays L.) - cow pea (Vigna unguiculata L.) intercropping on light distribution, soil temperature and soil moisture in arid environment. J. of Food, Agric. \& Environment 8 (1): 102 - 108.

Akbar. A. I. N.; H. Z. Khan.; R. N. Abbes and J. Ahmad (2012). Productivity of summer legume forage intercropped with maize as affected by mixed cropping in different sowing techniques. The J. of Ani. \& Plant Sci. 22(3): 758-763.

A. O. A. C. (1980). Official Methods of Analysis, $13^{\text {th }}$ Ed. Association of Official Analytical Chemists, Washington, D. C. USA.

A. O. A. C. (1975). Official Methods of Analysis, $13^{\text {th }}$ Ed. Association of Official Analysis Chemists, Washington, D. C., USA.

Chivas, W.; C. Chiduza; P. Nyamudeza and D. F.S. Murungu (2011). Evaluation of cow pea (vigna unguiculata (L.) Walp.) varieties for intercropping with maize (Zea mays L.) and sorghum (Sorghum bicolor L.) in Semi - Arid Area of Zimbabwe. International Scientific Coference on organic Agriculture, Adelaide, Australia, 177 - 190.
Dahmardeh M.; A. Ghanbari; B. A. Syahsar and M. Ramrodi (2010). The role of intercropping maize (Zea mays L.) and cow pea (Vigna unguiculata L.) on yield and soil. African Journal of Agricultural Research 5(8): 631636.

Egbe M. O. and J. A. Idoko (2012). Evaluation of pigeon pea genotypes for intercropping with maize and sorghum in Southern Guinea Savanna: Economic benefits. Inter. J.of Agriculture and Forestry 2 (1): 108-114.

El - Aref, Kh. A. O.; A. S. Abou - El - Hamd; M. M. Ibrahim and A. Y. Mahdy (2013). Response of cow pea to intercropping with maize grain yield. Minia J. of Agric. Res. and Develop. 33 (2): $183-210$.

Elena M. D. and G.V. Roman (2010). Research on productivity and yield quality of maize and cow pea intercropping in the organic agriculture system. Scientific Papers, UASVM Bucharest, Series A, 1222-1239. Romania.

Hall, R.L. (1974). Analysis of the mature of internce between plants of different species. Aut. J. Agric. Res. 25: 749-756.

Haruna I.; M. Aliyu and S. M. Maunde (2013). Competitive behayiour of sesame/groundnut intercropping systems under varying poultry manure rates and planting arrangement. Sus. Agri. Res. 4 (2). 3-14.

Johanson, R. E. (1967). Comparison of methods for estimating cotton leaf area. Agron. J., 1 (3/4): 73-79.

Kamal - Eldin M. F. (2010). Growth and yield of groundnut, sesame and rosella in an Acacia Senegal agroforestry system in North Kordofan Sudan. J. of Agri. and Rural Devel. 11 (1): 35 40.

Mahdy A.Y. and M. A. A. El-Said (2015). Response of sesame for intercropping with some forage crops. Minia J. of Agric. Res. Develop. 35 (1): 139-157.

Mahdy A.Y. and M. A. A. El-Said (2017). Effect of intercropping and cutting date for guar on soybean yield.. Inter. J. of Agri. and Eco.Devel. 5(2): 82-102.

Mc -Gilchrist, C. A. (1965). Analysis of competition experiments. Biometrics, 21: 975-985. (C. F. Field Crop Abst., 32 (1): 5-6, 1979).

Ministry of Agric ; Agr. Res. Center, Centeral Adem. Of Agr. Extension (2016-2017): Year book , 122 for summer crops, 21, 22, 84, 111, and 112 .

Quainool , A. K.,; J. K. Bissue and I. K. Aidoo (2012). Intercropping performance of maize, sorghum and soybean in row-replacement series systems. International Scientific Conference On Organic Agriculture, Adelaide, Australia, October $108-119$. 
Oyeogbe A.; O. Ranti; S. Vaghela and B. Patel (2015). Towards sustainable intensification of sesame-based cropping system versification north western India. J. of Food Security 3(1): $1-5$.

Puste A. M.; T. K. Mandal; S. K. Gunri; T. S. Devi and B. R. Pramanik (2014). Growth, yield and advantages of green gram - sesame intercropping under different moisture regimes in new alluvial zone of west Bengla. J. of Crop and Well 10 (1): 19 - 21.
Steel, R. G. D. and J. H. Torrie (1980). Principle and Procedures of Statistics, a Biometrical Approach. Mc Grow-Hill Book CompanySecond Edit. USA.

Willey, R. W. (1979). Intercropping, its importance and research needs. Part 1, Competition and yield advantages. Field Crop Abst., 32 (1): 110.

تأثير تحميل وتوزيع نباتات الجوار مع محصول الأرة الشامية

\author{
أحمد يوسف مهذى \\ قسم المحاصيل - كلية الزر اعة - جامعة الأزهر بأسيوط
}

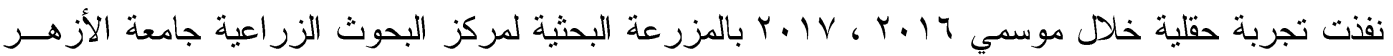

فرع أسيوط لدر اسة إستجابة الجوار للتحميل مع محصول الذرة الثامية وعلاقة ذلك بالمحصول ومكوناته و التحليل

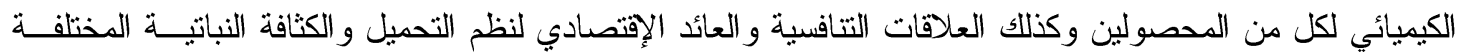
تحت الدراسة مقارنة بالزر اعة المنفردة لكل محصول، كانت أصناف الذرة الثامية و الجوار المستخدمة في الدراسة هي هجين ثلاثي نفرتيتي - ب و الصنف المحلى على الترتيب. وقد إثتنملت الدراسة خلا كل كل موسم زر اعــة الــذرة

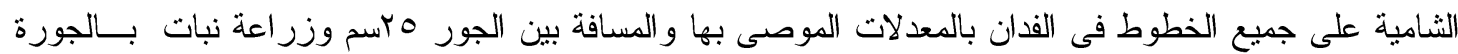

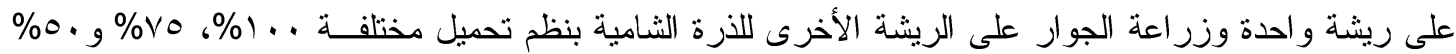

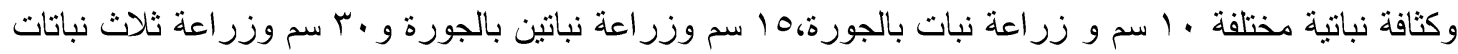

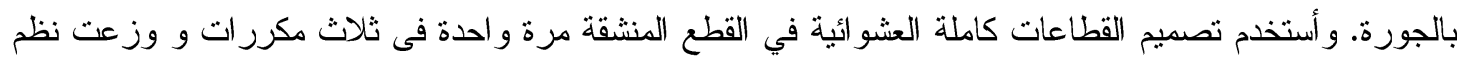
التحميل في القطع الرئيسية بينما وزعت مسافات الزر اعة في القطع المنشقة.

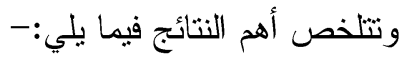

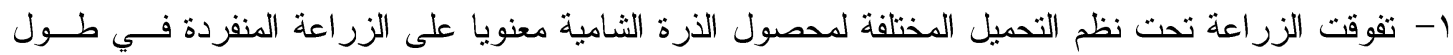

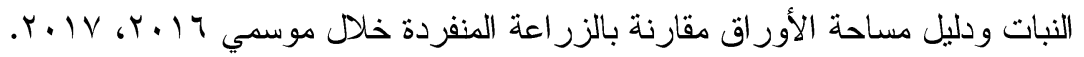

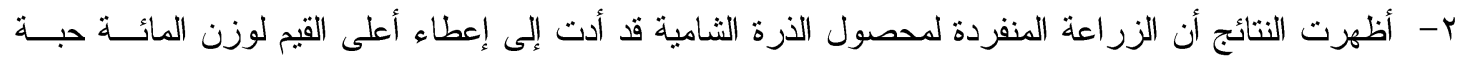

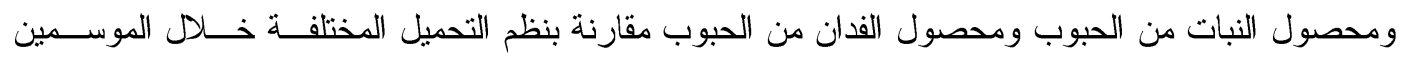

$$
\text { .r. IV G Y I T }
$$

ץ- أدى تطبيق نظام التحميل (P P) لمحصول الذرة الثامية إلى نقص في وزن المائة حبة ومحصول النبــات مـن الحبوب ومحصول الفدان من الحبوب خلال الموسمين مقارنة بنظم التحميل المختلفة وعلى النقيض أدى النظــــام (P 9 )

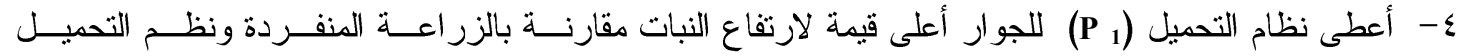

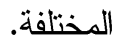




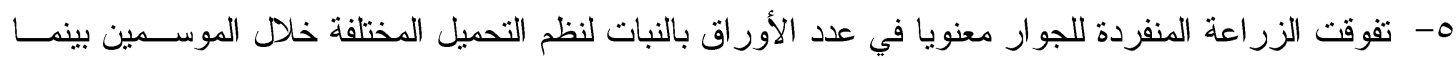

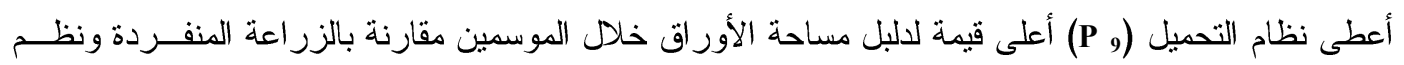
التحميل المختلفة.

צ- - أدت الزر اعة تحت نظام التحميل (P P) الحصول على أعلى محصول علف أخضر بالفــدان مقارنــة بــنظم التحميل المختلفة خلال الموسمين.

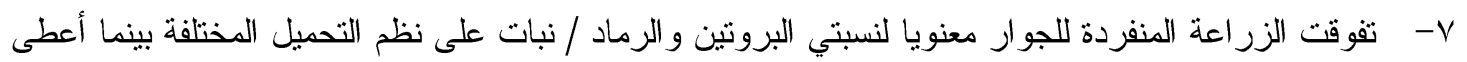

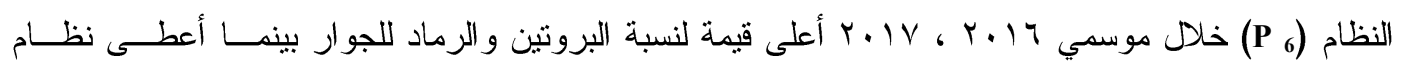
التحميل (P P) أعلى قيم لنسبة الألياف الخام لمحصول الجوار مقارنة بنظم التحميل المختلفة خــلال موسـمي . Y. YV , Y. IT

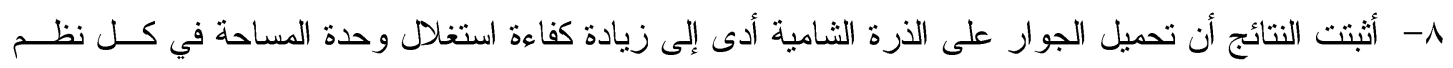

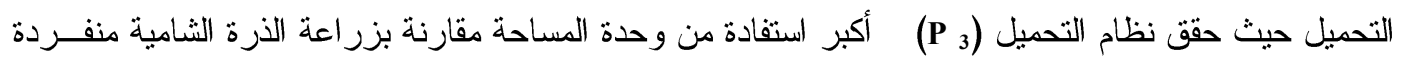
بينما نجد أيضا نفس الاتجاه سائدا عند تطبيق معامل الحشد النسبي لكلا المحصولين وقد أعطى محصول الذهام الذرة

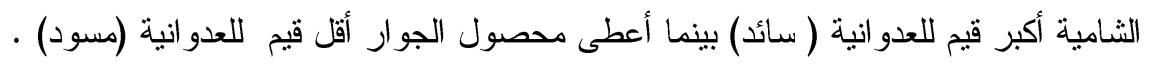

\section{العائد الاقتصادي للقدان ( بالجنية المصرى):}

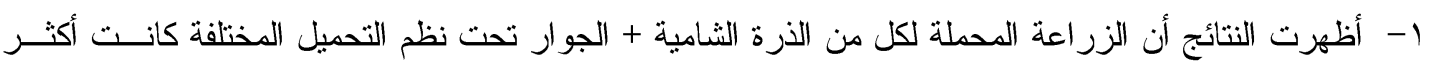

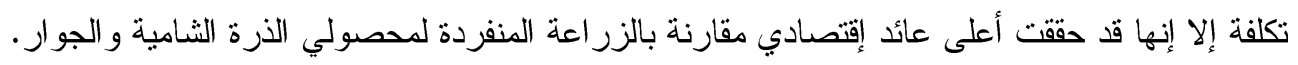

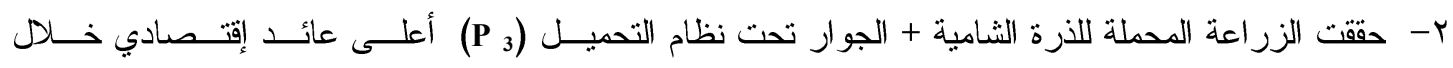

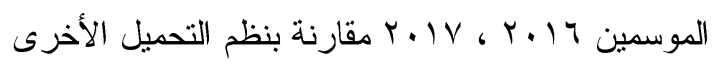

